\title{
脳性麻痺児の足部変形に対する Grice 手術成績
}

\author{
鹿児島県立整肢園 \\ 神 保 俊哉. 肥後勝 \\ 内 野潔
Postoperative Evaluation of Grice Subtalar Arthrodesis in Cerebral Palsy Children
by \\ Toshiya Jinbo, Masaru Higo and Kiyoshi Uchino \\ Kagoshima Prefectural Crippled Children's Hospital
}

\begin{abstract}
We evaluated the Grice subtalar arthrodesis which had been performed in cerebral palsy children for treatment of 22 planovalgus feet. We performed Grice subtalar arthrodesis with lengthening of the Achilles tendon and soft tissue release with internal fixa-tion using $\mathrm{K}$-wires in order to correct planovalgus foot deformity. Postoperatively the feet were immobilized with a plaster cast for 6 weeks.

The average age at surgery was $9.9 \pm 3.9$ years, the average duration of follow-up was $22.3 \pm 15.5$ months. Of the 22 planovalgus feet, 21 achieved excellent and satisfactory results but one foot with a varus deformity had unsatisfactory results. Two feet in one patient resulted in graft failure. The Grice subtalar arthrodesis was an effective surgical procedure for treatment of planovalgus feet in cerebral palsy children.
\end{abstract}

Key words : Grice Subtalar Arthrodesis (グライス距骨下関節固定術), Cerebral Palsy（脳 性麻痖), Planovalgus（外反扁平足）

はじめに

Grice $^{3)}$ は，最初にポリオ麻痺性外反扁平足に対す る距骨下関節外固定術を報告したが, その後, 脳性麻 㾝外反扁平足の治療に後足部外反の stabilizer とし て広く用いられるようになってきた，今回，我々も痙 性脳性麻盘の足部変形の治療に Grice 法を応用し, その治療成績について検討したので報告する.

\section{対象}

対象症例は，男児 9 例，女児 6 例の 15 例 24 足であ り, 麻痺型は, 対麻痺 12 例 21 足, 片麻疩 3 例 3 足で あった。手術時年齢は, $5 \sim 18$ 歳, 平均 $9.9 \pm 3.9$ 歳 である。術後経過期間は，8 8 月 61 月，平均 22.3 \pm 15.5 か月である。麻瘦性足部変形として外反扁平 足 13 例 22 足を認め, このうち舟底足変形を 3 例 5 足に
認めた。高度内反尖足は片麻痷の 2 例 2 足に認めた。 外反扁平足例には術前疼痛なく, その術前の歩行能力 は, 屋外独歩 1 例, 屋外支持歩行 5 例, 屋内支持歩行 5 例, 歩行不能 2 例であった. 内反尖足の 2 例には術 前足底に有痛性胼胝があり，1例は疼痛のため歩行不 能であった。

\section{手 術 方 法}

手術は, Griceの方法に準じて足部外側皮切により 足根洞を展開し, 変形矯正後, 矯正位保持と良好な骨 癒合を得るため距踵関節・足関節と距舟関節をキルシュ ナー鋼線により内固定を行い, 骨移植した. Grice 手 術と同時に良好な変形矯正を得るためアキレス腱延長 術 22 足, 後内方解離術 6 足, 後内外方解離術 5 足, 距舟関節包縫縮術 7 足の軟部組織手術を行った。また 高度変形の 2 足には踵立方関節固定術を，7足には外 
反拇趾手術も行った。 内反尖足の 2 例 2 足には, 三関 節固定の適応があったが，足部短縮を避けるため後内 外方解離術, Grice 手術, 踵立方関節固定術を行った。

結

果

調査時，外反扁平足例には疼痛はなかったが，軽度 外反扁平を 2 例 4 足に認めた。 1 足に内反変形を認め たが，この症例は術後舟底足変形の良好な矯正を得た が, 術後 4 年半頃より筋不均衡による内外変形を生じ てきたものである．歩行能力は，調査時にも術前と同 様であったが，歩行不能であった 2 例は術後支持起立 可能となった。 内反尖足の 2 例は, 術後胼胝, 疼痛が 消失し, 歩行不能であった 1 例は独歩可能となった。

Grice 手術の移植骨は 18 足は脛骨より，4 足は腸 骨， 2 足は腓骨より採取した。調査時 22 足に良好な 骨癒合が得られていた。外反扁平足の 1 例 2 足は再手 術後も骨癒合不全となったが，術後 1 年半の調査時, 外観的に変形なく足底接地可能な足部となっていた.

X線学的に立位側面像で足根骨の骨配列を検討した. Talo-calcaneal angle の平均值は, 術前 $52.4 \pm 10.3^{\circ}$ より術後 $33.6 \pm 7.4^{\circ}$, 調査時 $35.0 \pm 7.3^{\circ}$ に改善した。 Talo-navicular angleは, 距骨前後上縁を結ぶ線と 舟状骨上下端後縁を結ぶ線とのなす角度で表し，距骨 と舟状骨との骨配列をみた。その平均值は術前 126.8 $\pm 18.8^{\circ}$ が術後 $99 \pm 12.1^{\circ}$, 調査時 $101.6 \pm 9.6^{\circ}$ に改善し た. Calcaneal Pitchの平均值は, 術前 $1.8 \pm 9.6^{\circ}$ よ り術後 $4.8 \pm 77^{\circ}$, 調査時 $3.9 \pm 8.0^{\circ}$ に改善した。

外反扁平足の術後成績評価は Gallien $5^{2)}$ の評価 基準にもとづいて 3 段階に評価した。 excellentは足 底接地可能な足で，外反なく，骨癒合良好なものであ る. Satisfactoryは，足部外観良好で，偽関節があつ ても安定性良好で，10 度以下の軽度外反の遺残する ものである。 Unsatisfactory は10 度以上の高度内・ 外反や足部の疼痛を有するものである，外反扁平足の 術後成績は, Excellent15 足, Satisfactory 6 足, 内 反変形を生じた 1 足は Unsatisfactory となり，22 足中 21 足，95\%に良好な成績が得られた。内反尖足 の 2 例では, Excellent 1 足, Satisfactory 1 足であっ た。

症

症例 15 歳, 男児。
術前高度の舟底足変形を呈し，X線写真で vertical talus を認める（図 1 - a ）. 後内外方解離術と Grice 手術を行い, 術後良好な足根骨配列と移植骨の骨癒合 が得られた（図 $1-b)$. 調査時も良好な足部形態が 保持されている（図1-c).

\section{考察およびまとめ}

脳性麻痺外反扁平足の発生機序について神前ら ${ }^{4)}$ は, 後足部関節の諸勒帯や足関節周囲筋などの laxity, Grice $^{2)}$ のいう距骨下関節の解剖学的構造上の不安定 性，下腿三頭筋の痤性・短縮による尖足，下肢各関節 の相互干涉による内旋，かがみ肢位などの要素により 発生すると述べている。この様な種々の脳性麻痺外反 扁平足の発生要因に対し, 距踵関節外固定により後足

a

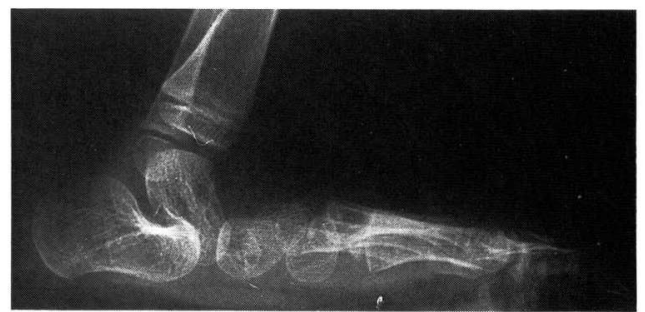

b

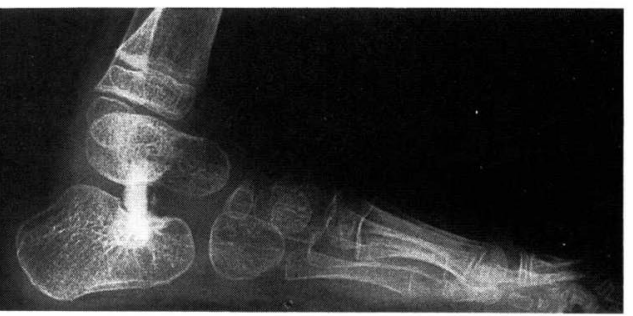

c

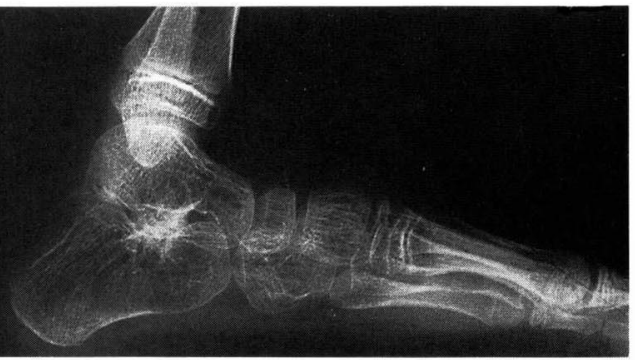

図 15 歳, 男児. 左足 X 線写真側面像.

a ）術前, vertical talus と足根骨の逆アーチ 配列を認める。

b ）術後 3 加月，良好な足根骨配列と移植骨の 骨癒合を認める。

c）術後 5 年の調査時, 距踵関節固定と良好な 足部形態を認める。 
部外反を安定化する Grice 手術は有効な方法であり, その手術成績は一般に 70〜 90\%に良好な成績が得ら れると報告され(1)2)4-6), 我々の外反扁平足症例では 22 足中 21 足, $95 \%$ に良好な成績が得られた。

我々は，変形矯正を容易にし良好な足根骨配列を得 るため可及的に軟部組織手術を併用した。我々の大半 の症例ではアキレス腱延長術により尖足矯正と距舟関 節包を縫縮して骨配列を整えたが, 変形高度で関節拘 縮がある場合には後内方解離術, 後内外方解離術等の 軟部組織解離術を行った. また矯正位の保持のためキ ルシュナー鋼線による内固定も行った.

脳性麻瘏外反扁平足の Grice 手術の偽関節の発生 率は 10 ３0\%と報告者 ${ }^{4-6)}$ によって異なっている. Dennyson and Fulford ${ }^{1)}$ は海綿骨骨移植と screw による内固定の併用により $93.7 \%$ の骨癒合が得られ たと報告している。森川ら ${ }^{5)}$ や大川ら ${ }^{6)}$ も一部の症例 にキルシュナー鋼線距踵関節の内固定を行っているが, 多くは内固定を用いていないようである.我々の症例 では脛骨皮質骨を主に移植骨として用い, 全例に内固 定を行い，22 足中 20 足（91\%）に骨癒合が得られ， 骨癒合に内固定が有効であった. 一方， 1 例 2 足では 再手術後も偽関節となったが, 骨配列は良好に保持さ れており，これは距舟関節包縫縮や距踵関節の㓔痕性 癒着により矯正位が保持され，足根骨関節面の軟骨 ·
骨成長により良好な骨配列での修復が生じたものと考 え，骨癒合不全が必ずしも不良な成績には結びつかな いようである。

Grice 手術は脳性麻疸児の足部変形に対する有用 な治療方法の一つの方法と考えるが, 我々の 1 足のよ うに正常足の形態に矯正され強固な骨癒合が得られた にもかかわらず，術後に筋不均衡により内反変形をき たすものもあり，成績向上のためには可及的に筋均衡 を得る必要があると考える。

\section{参 考 文 献}

1) Dennyson W.G. and Fulford G.E.: Subtalar arthrodesis by cancellous graft and metallic internal fixation. J.Bone Joint Surg. 58-B : 507-510, 1976.

2) Gallien R. et al.: Subtalar arthrodesis in children. J Pediatr Orthop 9:59-63, 1989.

3) Grice, D.S.: An extra-articular arthrodesis of the subastragalar joint for correction of paralytic flat feet in children. J.Bone Joint Surg. 34-A : 927-940, 1952 .

4）神前智一ほか：脳性麻㿔児の外反扁平足に対する GriceGreen 手術の成績. 整形外科, $43: 1403-1412,1992$.

5）森川憲輝ほか: 脳性麻瘪時の足部外反変形に対する距 踵関節外固定術（Grice-Green法）の検討. 足の外科研 究会誌, $7: 66-69,1986$.

6）大川敦子ほか：脳性麻痺児に対する Grice-Green 手術 の経験．中部整災誌，22:1621-1623, 1979. 